\title{
Information Sources Preference of Post Graduate Students in Federal University of Technology Owerri, Nigeria
}

\author{
Anunobi, Chinwe Veronica (Dr.) Emezie, Nkeiru Amauche* \\ The Library, Federal University of Technology Owerri
}

\begin{abstract}
The paper investigated postgraduate students in federal university of technology Owerri Nigeria to find out the information sources preferred for research. The descriptive survey employed questionnaire and interview as instruments for data collection. A total of one hundred questionnaires were distributed to postgraduate students from various departments while fifty were returned and found useable for the study. Data were analyzed with percentages while charts were employed to present results of the findings. The study showed that postgraduate students in FUTO prefer electronic sources of information for research. Responses from both the questionnaire and interview showed that the major reason for preferred sources were easy and quick access, ease of use, convenience and currency. It was also discovered that very few of the postgraduate students identified database subscription from the library as available sources of information for research. This implies that library prints and subscribed databases were not popular among postgraduate students as preferred sources of information for research. This finding however, point to the need for aggressive information literacy campaign for postgraduate students tailored towards creating awareness and use of library resources and databases to justify the university library's role in tertiary education.
\end{abstract}

Keywords: Information sources, Postgraduate students, University libraries, Electronic resources, Nigeria.

DOI: $10.7176 / \mathrm{IKM} / 10-1-04$

Publication date: January $31^{\text {st }} 2020$

\section{Introduction}

Scholarship is transiting from use of traditional print media to a predominantly based electronic format as a result of the changing information landscape. Information users dwell in an electronically saturated environment where communication technologies such as mobile devices and its attendant e-gadgets have become the order of the day. That notwithstanding, reliance on traditional sources of information have not been completely relegated. Instead, librarians are re-inventing and repackaging to keep track with the changes in the way and manner information is accessed. To remain at the apex of information provision, library operations and services are continually transforming to meet prevailing needs. One major strength of the library is the provision of information sources in various formats to support academic activities.

Information sources can be anything that contains or provides information and increases or adds to existing knowledge. Information sources can be formal or informal and ranges from humans, traditional prints, non-prints to electronic media. Prior to the emergence of electronic environment, traditional sources adorned library shelves but today, university libraries are acquiring different sources some of which are electronic in nature to connect with the changing learning and research environment. At the Federal University of Technology Owerri Nigeria, post graduate students rely on various information sources to fulfill the requirements for award of an academic degree. The postgraduate students' academic programs are deeply rooted in science, technology, engineering and management. These programs are run by various schools in the university namely: School of Agriculture and Agricultural Technology (SAAT), School of Engineering and Engineering Technology (SEET), School of Basic Sciences (SOBS), School of Environmental Sciences (SOES), School of Health Technology (SOHT), School of Management Technology (SMAT) and School of Physical Sciences (SOPS). FUTO's Postgraduate school has grown enormously to become one of Africa's finest. Equipped with a wide array of tools, FUTO's Post Graduate School brings together accomplished professionals and ambitious students who share a common passion for their fields.

The postgraduate programs in FUTO include Postgraduate Diploma (PGD), Masters in Science (MSC), Engineering (M.Eng), Public Health (MPH), Business Administration (MBA), and Doctor of Philosophy (PHD) degrees. These programs demand that postgraduate students connect with various information sources that cover their specific areas of expertise. It is not enough that university libraries play crucial roles in providing access to information. Rather, ensuring that the information so provided meets user preference should be a fundamental concern. That is why, Ezeala and Yusuff (2011) states emphatically that library services to institutions should not be restricted to the acquisition, processing, storage and dissemination of print resources but should also emphasize what users prefer in terms of the way and manner information is provided. Hence, there is need to ascertain the information sources preference of postgraduate students in Federal University of Technology Owerri, Nigeria. 


\section{Statement of the problem}

The postgraduate student is a knowledge creator. He conducts research and produces results which adds to existing knowledge. In doing so, he is confronted with myriad of information sources. However, the university library provides a haven for organized knowledge through the provision of various information sources that support educational activities. With the financial downturn besieging many universities, the budgetary allocation to libraries continues to dwindle. This unpalatable situation has necessitated the need for provision of information sources that align with user preferences. Bearing in mind that postgraduate students are knowledge generators, it is not clear what information sources they prefer as they wade through the research domain. Hence, understanding the information sources preference of postgraduate students will be useful in the provision of sources which address their specific needs and promote quality research.

\section{Objectives of the study}

1. Find out the sources of information resources available for post graduate students in FUTO

2. Identify the information sources used for research by the postgraduate students

3. Determine the sources of information preferred by the postgraduate students

4. Ascertain the reasons for the preferred sources of information.

\section{Theoretical underpinning}

The theoretical framework adopted for this study hinges on the human information behavior model proposed by Wilson (2000). The author revealed three types of information behavior exhibited by humans as they seek and use information for various purposes. These include: information seeking behavior, information searching behavior and information use behavior. Information seeking behavior is the theoretical framework upon which the current study is based. Wilson (2000) defines information seeking behavior as the purposive seeking for information as a consequence of a need to satisfy some goal. In the course of seeking, the individual may interact with manual information systems (such as a newspaper or a library), or with computer-based systems (such as the World Wide Web). Wilson (1981) explains that information seeking behavior is prompted by the individual's physiological, cognitive and effective needs. Furthermore, he observes that these needs may be driven by the individual's personal makeup, his/her responsibilities in life or job demands, the environment in which the person exists to carry out his/her responsibilities which could be digital, social, educational, political or economic.

The above theory implies that there are underlying factors that instigate information seeking behavior and also influence information source preferences. These can be social, economic, political, cultural or educational (Kehinde, Obi, Akinade \& Anyim, 2016). For instance, demographic factors such as gender has been identified to influence source preference (AbdulKarim, \& Hasan 2007; Liu, 2008). As observed by Liu (2008), males preferred printed media compared to females. In terms of discipline of study, Liu (2006) agrees that prints and electronic resources preferences and use can vary across different disciplines. In corroborating this assertion, several authors such as Nwagwu (2012) found that students from engineering used libraries more than their counterparts in the arts though the difference was quite minimal. Similarly, George et al (2006) study found that preference to print sources was more pronounced with students in sciences and humanities. Also, Levine-Clark (2006) discovered that maximum number of the students had greater preference to print resources compared to online materials. Conversely, Kerrens, Madden and Fulton (2004) identified that students of engineering preferred sources that were less strenuous to access such as the internet. In the humanities, Liu (2006) discovered that students studying social sciences and library and information sciences, used printed materials most of the time, whereas those in business or computer science students preferred using electronic documents most of the time. This finding corroborates that of Echezona, Okafor and Ukwoma (2011) who found that postgraduate students from library and information science made mostly utilized journals for their research work. However, Mucnjak (2009) provides a contrary view in his finding that social sciences make more use of e-resources than humanities do. In another study by Saiti and Prokopiadou (2009), they found that internet was the primary information source for Greek post-graduate students from different study areas.

Another factor found to influence information source preference and seeking behavior is level of study. George et al (2006), observed that the information seeking behavior of postgraduate students was influenced by the faculty who provide guidance at the initial stage of the research process. These lecturers, academic advisers and professors recommend certain resources which are deemed useful. As a result, the postgraduate students naturally flow with the recommendations of their lecturers because they are confident in their lecturers and would consider the sources as highly scholastic and reliable. In another vein however, Friedlander (2002) and Liu (2006) provide that faculty and graduate students appear to expect a combination of print and electronic resources, while undergraduates appear more willing to live in an entirely online world. However, Weisberg (2011) identified that most students still prefer print compared to electronic materials. Kumah (2015) notes that researchers in the current environment appear to be at home with a variety of information sources ranging from print to electronic sources in different variations such as search engines, websites, databases, servers etc 
Be that as it may, it is recognized that the changing electronic environment has also influenced the information seeking behavior as well as source preference of post graduate students. Liew, Foo, and Chennupati (2000) and Stravrianess, Stewart \& Harmer (2008) found that maximum number of graduate students have preference for and are increasingly using electronic journals than print journals. This is because the Internet is adjudged the best medium for quick access and retrieval of information in the research process. Hence, Prabhavathi's (2011) study reveal that internet was used by majority of post graduates for their academic work. This is not out of place since the average postgraduate student is submerged in an electronic environment. This has created a society where people are techno savvy and exhibit dexterity in using technology. Furthermore, Hamade and Al-Yousef (2010) notes that the reason for postgraduate preference of electronic sources is that it provides access to information with speed and precision. These assertions lend credence to the notion that millennial students are highly techno centric and display unflinching penchant for digital things.

Studies have shown diverse reasons for information source preferences. Authors agreed on common grounds that changing environment, ease, reliability, convenience, speed, currency of information and accessibility were major factors influencing academic internet use (Hall and Parsons 2001; Lacovic, 2014; Pascoe, Applebee and Clayton, 1996 \& Pather, 2004). Earlier studies such as Ray and Day (1998) identified that it is faster to use electronic information sources than traditional prints especially when searching indexes and back issues; electronic sources are less complicating when using various search terms, and allows simultaneous use of multiple tabs which is not the case when consulting print sources. Specifically, Saiti and Prokopiadou (2009) add that the main reason why Greek post graduate students prefer electronic sources is because of reliability and currency of information, any time anywhere access and quick retrieval. Another reason given by Ozoemelem (2009) is that library electronic resources (databases) appear not to be straightforward unlike an Internet search engine which shows too many resources for a single search in any area. According to the author, this is not so in the library because students have to choose a particular database and be more selective in the search words they use. Furthermore, Liu (2006) and Sellen \& Harper (2002) identify that the reason for preference to print sources is that when comparing many documents, one can view different documents on paper at the same time, whereas this cannot be easily done with computer screens. Prabhavathi (2011) avers that the reason why postgraduates were not using books is lack of adequate copies of books and absence of current editions.

The capacity a source has to satisfy an information need has been considered as reason for information source preference. For instance, Joseph \& NKebem (2011), view that information that is most sought after and used is that which is congruent with the need for which it is required. Also, Echezona, Okafor and Ukwoma (2011) reason that why postgraduates in library and information science use more journals was because academic journals constitute major sources of information for any meaningful research to be carried out.

Literature so far reviewed provoked divergent views on information source preference of post graduate students. While most of the studies maintain that postgraduates prefer electronic sources, some demonstrate a mixture of print and electronic or hybrid sources. Demographic variables (such as gender, discipline, level of study) and environmental factors were also identified to play a critical role in information source preference. In the light of the above presentations, literature was not found on information source preference of postgraduate students in FUTO. As a result, similar research is needful to know if postgraduate students in FUTO share same experiences or otherwise with their counterparts in other regions.

\section{Method}

The study adopted a qualitative and quantitative research approach. Questionnaire and interview were employed as data collection instruments. Studying the entire postgraduate students in FUTO will not be feasible due to accessibility, time and resources. As a result, 100 postgraduate students were sampled for the research. Questionnaire were distributed to students in various departments in the postgraduate school at the Federal University of Technology Owerri, Nigeria with the help of postgraduate students who were acting as course representatives. The questionnaire was structured towards identifying information sources available for research, information sources used for research, sources of information preferred by the postgraduate students and reasons for the preference. Out of this number of respondents, the researchers employed accidental sampling to further interview 10 of the respondents in order to elicit their opinion on reasons for information source preference. 50 copies of the questionnaire were returned and found useable for the study thus representing a $50 \%$ response rate on the distributed questionnaire. Data were analyzed using percentages while charts were employed to present result of the findings.

\subsection{Results}

The questionnaire returned showed number of responses from the various schools in Federal University of Technology, Owerri. Figure 1 below shows that the School of Engineering and Engineering Technology (SEET) had the highest number of respondents $14(27 \%)$ whereas no questionnaire was returned from the School of 
Health Technology (SOHT).

\section{Figure1: Return rate of questionnaire}

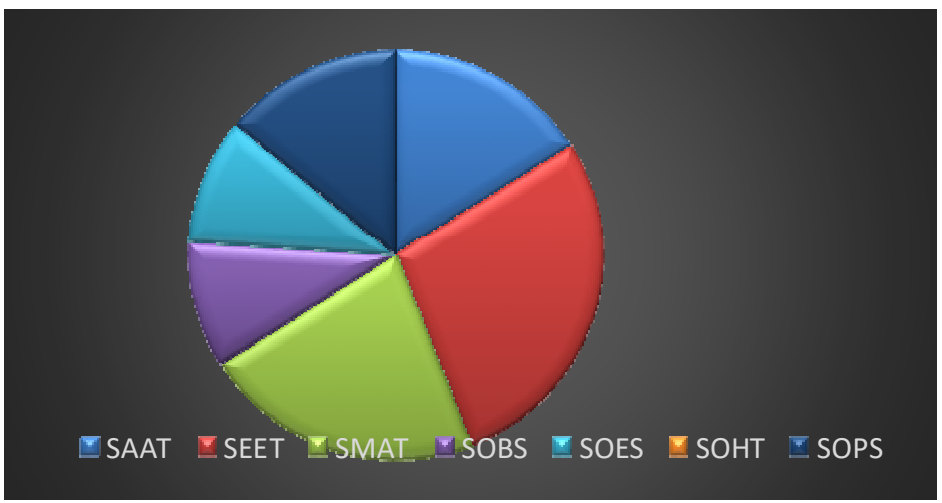

$11(22 \%)$ of respondents were from School of Management Technology (SMAT), 8 (16\%) respondents emerged from School of Agriculture and Agricultural Technology (SAAT), 7 (14\%) responded from School of Physical Sciences (SOPS) while 5 (10\%) responded from School of Basic Science (SOBS) and School of Environmental Sciences (SOES) respectively.

\section{Figure 2: Demographic characteristics of postgraduate students in FUTO.}

Out of the total number of 50 respondents, $41(82 \%)$ were males while $9(18 \%)$ were females. This gender gap may be attributed to the academic structure of the institution as FUTO is science, engineering and technology based. Hence, males appear to dominate these courses than the females.

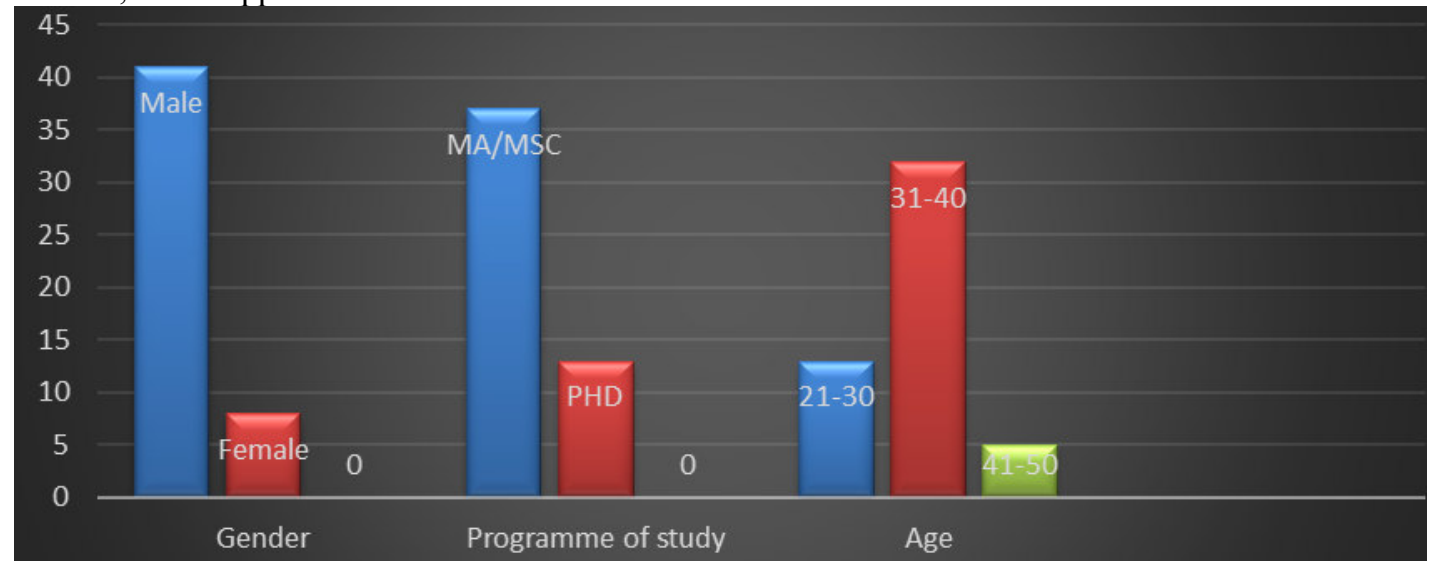

Going by the postgraduate programs, 37 (74\%) of the respondents are Master Degree students while 13 (26\%) are doctoral students in various fields. However, there was no response from students in the postgraduate diploma program. In terms of age, $13(26 \%)$ of the respondents are between the age of 21 - 30 years, 32 (64\%) fall between the age of $31-40$ years. Only 5 (10\%) of the respondents fall within 41-50 years. This means that majority of the postgraduate students are young adults since they fall within the age bracket of 31-40 years. 
Figure 3: Sources of information available for research.

Respondents were asked to identify the sources of information available for research. The figure below indicates various sources identified by postgraduate students for their research.

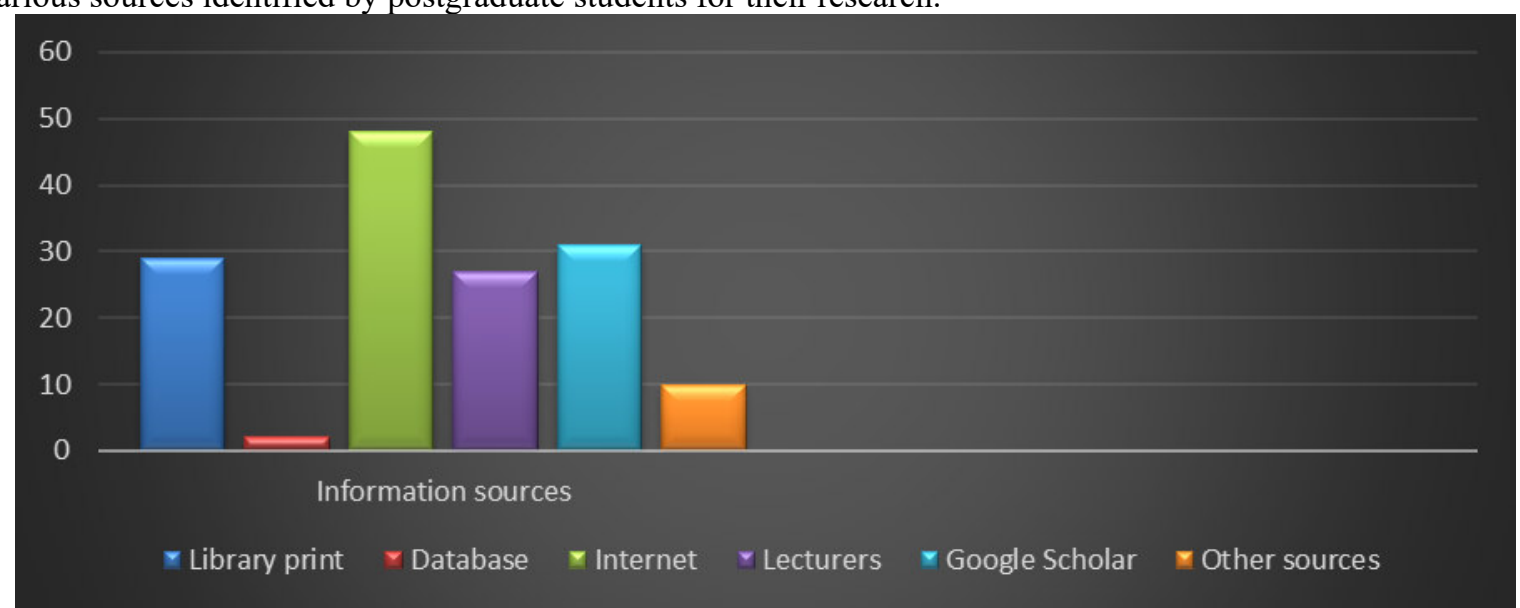

Majority of the respondents $48(96 \%)$ identified the internet as source of information available for research, 29 $(58 \%)$ indicated library prints while google scholar was identified by $31(62 \%)$ of the respondents. Also, 27 (54\%) of the respondents indicated lecturers recommendation as source of information. Other sources such as publications from government and companies were identified by $10(20 \%)$ of the respondents. However, only 2 (4\%) identified database subscription from the library as source of information available for research. The revelation here is that postgraduate students in FUTO are not fully aware of databases subscribed by the university library which are available for research.

\section{Figure 4: Information sources used for research by the students}

The study sought to identify sources of information used for research by the postgraduate students. Findings are summarized in the figure below.

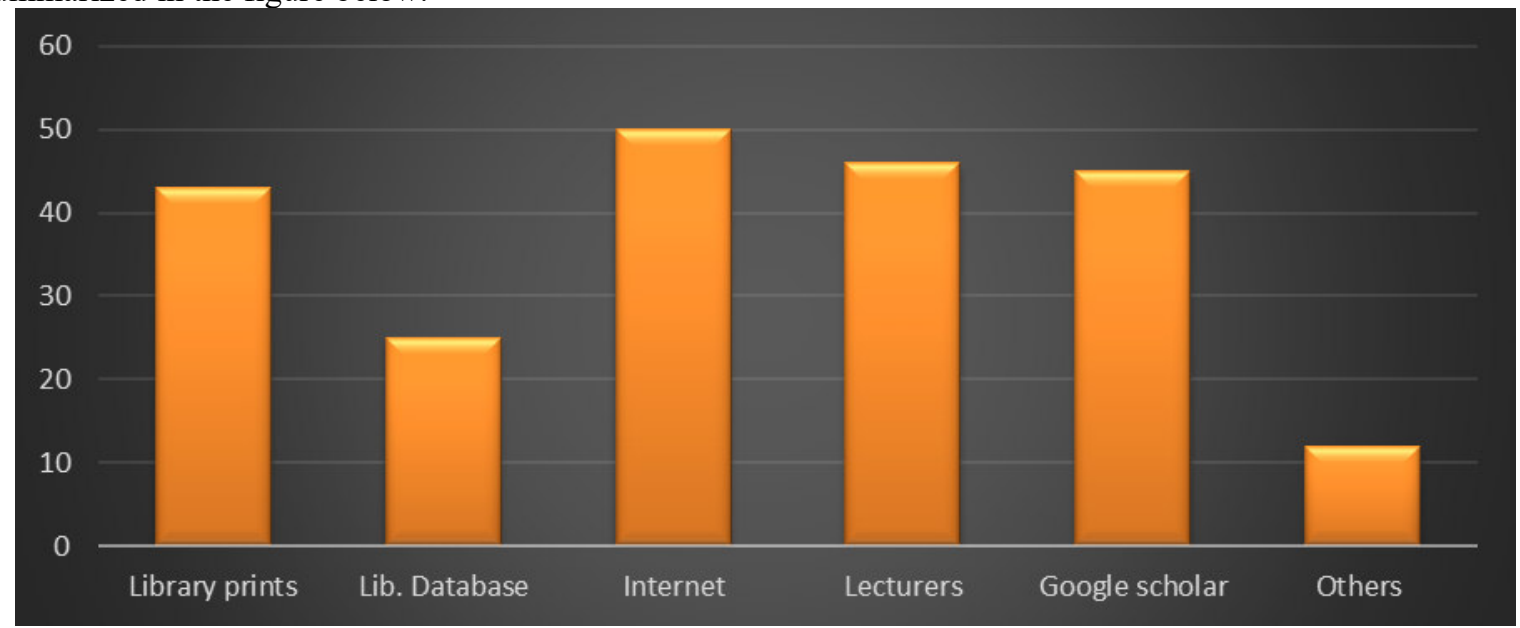

Breakdown of the analysis show that internet 50 (100\%) is the most information source used for research. This finding tally with Prabhavathi's (2011) study which reveal that internet was used by majority of post graduates for their academic work. $46(92 \%)$ of the respondents indicated lecturer's recommendation. This is in line with George et al (2006) who observe that the information seeking behavior of postgraduate students was influenced by the faculty who provide guidance at the initial stage of the research process. These lecturers, academic advisers and professors recommend certain resources which are deemed useful. As a result, the postgraduate students naturally flow with the recommendations of their lecturers because they are confident in their lecturers and would consider the sources as highly scholastic and reliable. Furthermore, $45(90 \%)$ of the respondents indicated Google scholar as information sources used for research while $43(86 \%)$ were positive on library prints. However, half of the respondents $25(50 \%)$ indicated databases subscribed by the library as information sources used for research. Other sources which include Newspapers, Personal textbooks, Magazines, Government \& Private organizations, Publications from Professional bodies were identified by 12 (24\%). 
Figure 5: Sources of information preferred by postgraduate students

Having identified the information sources used for research, it was necessary to determine sources preferred by the respondents in their research. The figure below shows the information sources preferred by the postgraduate students.

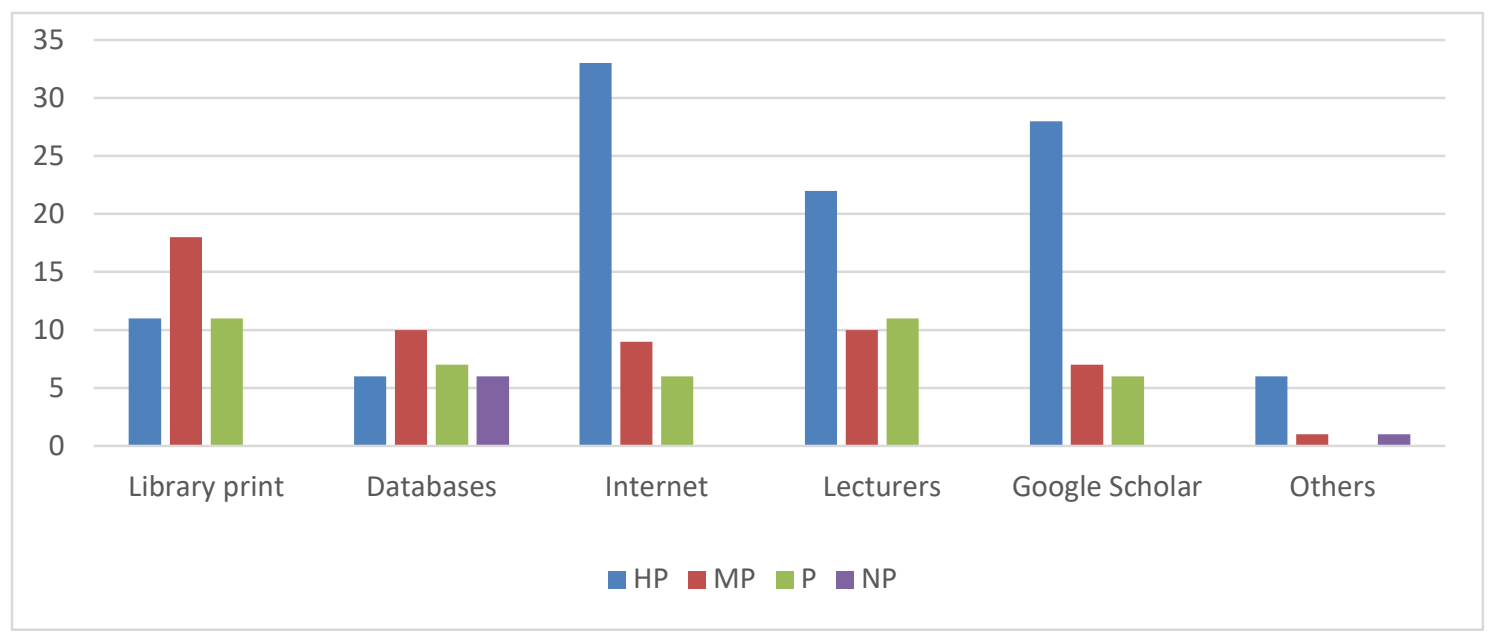

Internet was highly preferred by most (33) of the respondents followed by Google scholar (28). This corresponds with previous studies which found that a vast majority of graduate students prefer electronic journals over print journals because they make their work easier and give them the information they need (Stravrianess, Stewart \& Harmer, 2008; Hamade \& Al-Yousef, 2010). Furthermore, almost half of the postgraduate students (22) highly preferred lecturers' recommendation. Only (11) of the respondents rated library prints as highly preferred while very few (6) highly preferred databases subscribed by the library. From the findings, postgraduate students' preference for library prints and databases subscribed by the library is low. This could be due to the complex search and retrieval process associated with accessing library prints and subscribed databases. This is in agreement with Ozoemelem (2009) is that library electronic resources appear not to be straightforward unlike an Internet search engine which shows too many resources for a single search in any area. According to the author, this is not so in the library because students have to choose a particular database and be more selective in the search words they use.

\section{Figure 6: Reasons for information source preference}

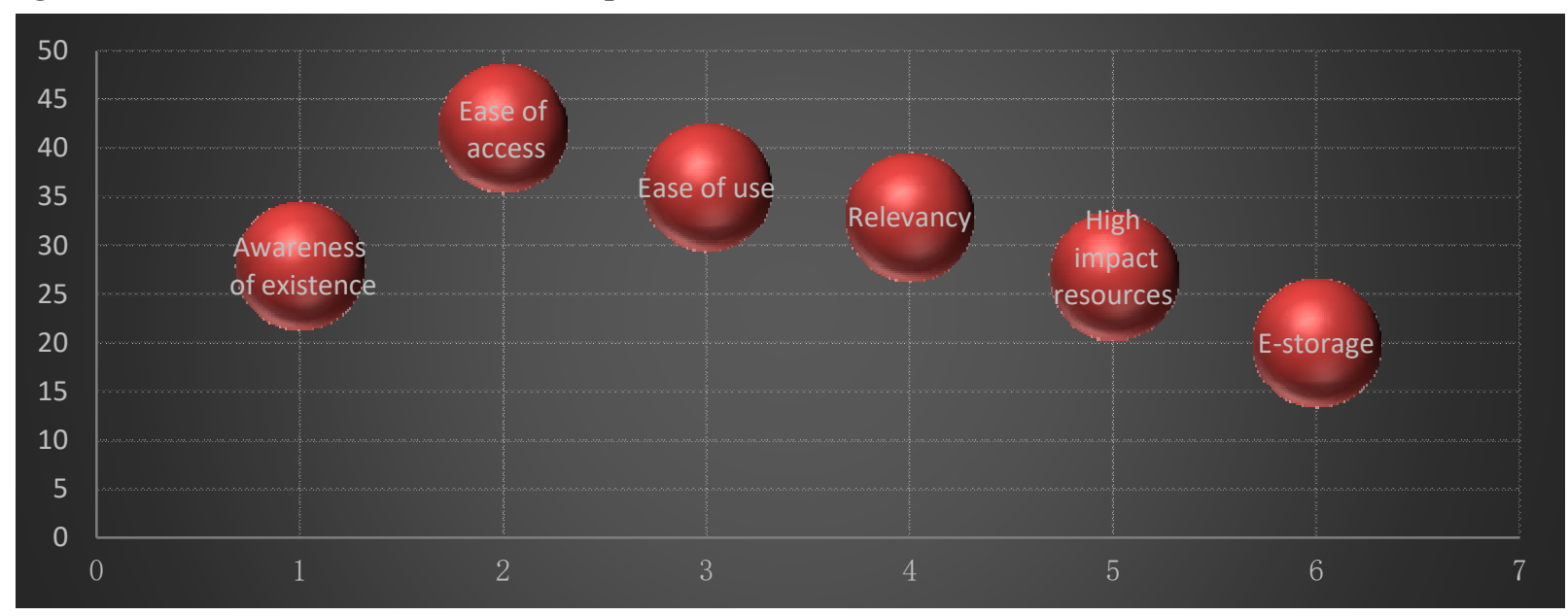

To fully understand the information sources preferred by postgraduate students for effective service delivery, it was pertinent to know the reasons for their preferences.

$42(84 \%)$ of the respondents indicated ease of access while $36(72 \%)$ stated that ease of use were among the reasons for information source preference. This finding tally with previous findings that ease of use, convenience, accessibility were reasons for information source preference (Applebee \& Clayton 1996; Hall \& Parsons 2001; Pather, 2004). Furthermore, $33(66 \%)$ indicated that the reason for preference was as a result of relevance of the source to their academic work. This is in line with Joseph \& Kebem (2011), that information that is most sought after and used is that which is congruent with the need for which it is required. Furthermore, $28(56 \%)$ indicated that the reason for preference is awareness of existence of the resources. 27 (54\%) indicated that the reason for 
source preference was based on high impact of the resources while $20(40 \%)$ indicated that the reason was based on ability of the source to be stored electronically example on flash drive, CD-ROM or other external devices.

Opinion of ten (10) postgraduate students who were interviewed on reasons for information source preference were equally analyzed. Whereas majority of the respondents interviewed preferred the internet (electronic sources) because of its attendant benefits of fast and easy access coupled with currency of information, it was observed that the major reason for not preferring library prints and databases was because of the complexities of search, access and retrieval.

\section{Figure 6.1 Response from interview}

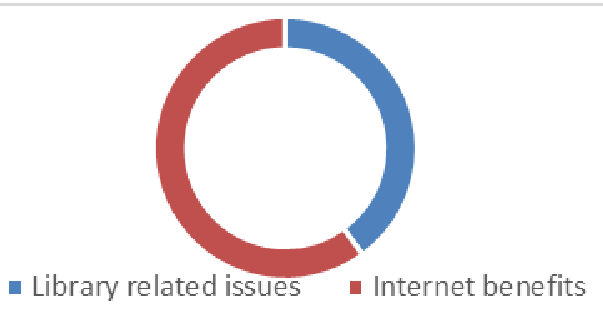

$6(60 \%)$ of the respondents indicated that they preferred internet because of the following reasons: preferred sources are highly scholastic, Current and easy access to internet, Internet sources are very reliable, Is less stressful, simplicity, Makes work easy, enjoyable and satisfying. These reasons are in line with the findings which have been earlier discussed. However, $4(40 \%)$ identified that they prefer using the internet due to the challenges they face while using library prints and databases. The reasons given include: access denial with library database, No access to library database due to password issues, searching in library database is complicating, Outdated research document in library. This is in line with Ray and Day (1998) who stated that it is faster to use electronic information sources than library traditional prints especially when searching indexes and back issues; electronic sources are less complicating when using various search terms, and allows simultaneous use of multiple tabs which is not the case when consulting print sources..

\section{Conclusion and implications}

The findings are in line with previous researches in that postgraduate students in Federal University of Technology Owerri, Nigeria prefer electronic sources of information for research (internet and google scholar). Responses from both the questionnaire and interview showed that the major reason for preferred sources were easy and quick access, ease of use, convenience and currency. However, findings revealed that very few of the respondents identified database subscription from the library as available sources of information for research. Also, a partial number of the postgraduate students indicated that library prints were among the information sources used for research whereas few of the respondents preferred these sources for research. This implies that library prints and subscribed databases were not popular among postgraduate students as preferred sources of information for research. The reason could be associated with the 'perceived' complex nature of library information search and retrieval processes. However, where library resources are not adequately utilized for research by postgraduate students will undermine the library's objective of supporting teaching, learning and research. Hence, the revelation from this study points to the need for an aggressive information literacy campaign for postgraduate students tailored towards creating awareness and use of library resources, databases and other services. This in turn will justify the university library's role in tertiary education.

\section{Recommendations}

Based on the findings, the following recommendations are made;

1. This study is a wakeup call on FUTO library to create awareness on subscribed databases which may be redundant due to lack of use. Librarians and staff should promote the use of these databases by being readily available to help with login details.

2. Information search and retrieval techniques should be taught to postgraduate students through the Information literacy program to acquaint and update their knowledge on available databases since some of these resources are highly scholastic and could depend on popular use for donors to renew subscription.

3. University library representatives and embedded librarians should organize library talks at postgraduate, faculty or departmental board meetings to keep the academic community up to date with library products and services especially as it affects the postgraduate students.

4. Library Management should ensure that Online Public Access Catalogue is up and running to ease the stress of manual searching which may discourage use of the library 
5. University library through embedded librarians should ensure that library fliers are made available to postgraduate students to acquaint them on databases and login details for easy access and quick retrieval of electronic sources.

\section{References}

Abdul Karim, N.S. \& Hasan, A. (2007). Reading habits and attitude in the digital age: Analysis of gender and academic program differences in Malaysia. Electronic Library 25 (3), 285-298.

Echezona, R.I.; Okafor, V.N. \& Ukwuoma, S.C. (2011). Information sources used by postgraduate students in Library and Information Science: A citation analysis of dissertation. Library Philosophy and practice

Ezeala, L.O \& Yusuff, E.O. (2011). User satisfaction with library resources and services in Nigerian Agricultural Research Institution. Library Philosophy and Practice. http://digital com $\mathrm{m} \quad \mathrm{o}$ ns. unl.edu/cgi/viewcontent.cgi?article=1595\&context=libphilprac \& sei-redi)

Federal University of Technology Owerri, Nigeria (n.d). Postgraduates. Retrieved from http://futo.edu.ng/postgraduate/

Friedlander, A. (2002). Dimensions and use of the scholarly information environment. Retrieved from: http://www.clir.org/pubs/reports/ pub110/contents.html.

George, C., Bright, A., Hurlbert, T., Linke, E.C., St. Clair, G. \& Stein, J. (2006) Scholarly use of information: graduate students' information seeking behavior. Information Research 11 (4), paper 272 [Available at http://InformationR.net/ir/11-4/paper272.html]

Hall, A. S., \& Parsons, J. (2001). Internet addiction: College student case study using best practices in cognitive behaviour therapy. Journal of Mental Health Counselling 23 (4), 312-327

Hamade, S. N. and Al-Yousef, S. 2010. The use of information resources by LIS graduate students in Kuwait. Library Review 59 (5), 360-369.

Joseph, O.J. and Nkebem, E.N. (2011) Analysis of Information Needs of Parliamentarians: A Study of Cross River State of assembly, Nigeria. A Paper Presented at IFLA 77th General Conference and Assembly, P. 5

Kehinde, A. A; Obi, S. A; Akinade, Adebowale, A. \& Anyim, A. O. (2016). Information Needs and Seeking Behaviour of Masters' Students in the Faculty of Communication and Information Sciences, University of Ilorin, Kwara State. Library Philosophy and Practice http://digitalcommons.unl.edu/libphilprac/1463

Kerins, G., Madden, R. and Fulton, C. 2004. Information seeking and students studying for professional careers: the cases of engineering and law students in Ireland. Information Research 10 (1). Retrieved at: http://InformationR.net/ir/10-1/paper208.html.

Kumah, C. H. (2015). A Comparative Study of use of the Library and the Internet as Sources of Information by Graduate Students in the University Of Ghana. Library Philosophy and Practice. Retrieved from http://digitalcommons.unl.edu/libphilprac/1298

Lacović, D. (2014). Students' information behaviour and the role of academic library. Libellarium VII (1), 119 139.

Levine-Clack, Michael. (2006). Electronic book usage: a survey at the university of Denver. Portal: Libraries and the Academy 6 (3), 285-299

Liew, C. L., Foo, S., \& Chennupati, K. R. (2000). A study of graduate student end-users; use and perception of electronic journals. Online Information Review 24 (4), 302-315.

Liu Z. (2006). Print vs. Electronic Resources: A Study of User Perceptions, Preferences and Use. Information Processing and Management 42 (2), 583-592.

Mučnjak, D. (2009). Usage of print and electronic resources at the Faculty of humanities and social sciences' library, University of Zagreb: analysis and comparison based on the usage statistics. In Proceedings of conference INFuture2009 "Digital resources and knowledge sharing" (pp. 461-468). Nwagwu, W. (2012). Information sources and information needs of postgraduate student in engineering and art in the University of Ibadan, Nigeria. Collection Building 31 (2), 66 - 77.

Oyegade, E. A (2000). Application of Information Technologies in Nigerian Libraries: Problems and Prospects. Information Technology in Library and Information Science Education in Nigeria. Fayose, P. O. and Nwalo, K. I. N. eds. Ibadan National Association of Library and Information Science Educators.

Ozoemelem, O.A. (2009). Use of Electronic Resources by Postgraduate Students of the Department of Library and Information Science of Delta State University, Abraka, Nigeria. Library Philosophy and Practice, 1-23.

Pascoe, C., Applebee, A., \& Clayton, P. (1996). Tidal wave or ripple? The impact of Internet on the academic. Australian Library Review 13 (2), 147-153

Prabhavathi, D. (2011). Information seeking behavior of postgraduate students in SPMVV, Tirupati (AP): a study. International Journal of Digital Library Services 11(2), 34-48

Ray, K \& Day, J. (1998). Student attitudes towards electronic resources. Information Research 4 (2) 1-13. http://information.net/ir/4-2/papers54.html

Saiti, A. \& Prokopiadou, G. (2008). Post-graduate students and learning environments: Users' perceptions 
regarding the choice of information sources, In The International Information \& Library Review 40 (2), 94 103. Retrieved at: http://www.sciencedirect.com/science/article/pii/S1057231708000143

Stavrianeas, S.; Stewart, M. \& Harmer, P. (2008). Beyond the printed page: physiology education without a textbook. Advances in Physiological Education 32, 76 - 80.

Weisberg, M. (2011). Student attitudes and behaviors towards digital textbooks. Public Research Quarterly, 27, $188-196$.

Williams, H. (2000). A Critical Review of Research and Statistical Methodologies within Human Resource Development Quarterly. Academy of Management Journal and Personal Psychology. 1995-1999, 841- 847. 